\title{
The Journal of the Gilded
}

Age and Progressive Era

Volume $4 \quad$ Number 2

April 2005

Editor's Note

\section{EsSAYS}

The Public Good and the Problem of

Pluralism in Lincoln Steffens's Civic

Imagination

James J. Connolly

Antiquity Bound: The Loeb Classical Library as Middlebrow Culture in the Early Twentieth Century Kevin B. Sheets

Performing 'Jiggs': Irish Caricature and Comedic Ambivalence toward Assimilation and the American Dream in George McManus's Bringing Up Father Kerry Soper

Book Reviews

www.jgape.org 
Editor: Alan Lessoff, Illinois State University

Associate Editor: Scott Nelson College of William and Mary

Associate Editor for Public History: Karen Cox, University of North Carolina at Charlotte Book Review Editor: Susan Traverso, University of Redlands

Founding Editor, 2000-2003: Maureen A. Flanagan, Michigan State University

Editorial Assistant: JoAnne Geigner

\section{Editorial Board}

Michael Les Benedict

Jack S. Blocker, Jr.

Ohio State University

University of Western Ontario

Charles W. Calhoun

Ruth Crocker

East Carolina University

Auburn University

Roger Daniels

Ellen Fitzpatrick

University of Cincinnati

University of New Hampshire

Joseph A. Fry

Murney Gerlach

University of Nevada, Las Vegas

Fremont, Ohio

Julie Greene

University of Colorado

Frederick Hoxie

University of Illinois

Nina Mjagkij

Harold Platt

Ball State University

Loyola University of Chicago

Judith Raftery

Eric Rauchway

California State University, Chico

University of California, Davis

Axel R. Schäfer

Nancy Unger

University of Keele

Santa Clara University

Articles appearing in this journal are abstracted and indexed in AMERICA: HISTORY AND LIFE and HISTORICAL ABSTRACTS

A member of the History Cooperative, the journal is available on-line at <wwwhistorycooperative.org $>$.

Change of Address: Contact <sdarr@,rbhayes.org >

Copyright permission: SHGAPE has contracted with Copyright Clearance Center, Inc., such that copyright permission requests for use of content owned by SHGAPE should be processed through CCC. Such requests may be submitted via their website at <www.copyright.com $>$. Requests may also be emailed to CCC at $<$ info@copyright.com $>$.

ISSN: 1537-7814 Publications Agreement No. 40639038

(C) Society for Historians of the Gilded Age and Progressive Era 


\section{Journal of the Gilded Age and Progressive Era Volume 4, Number 2, April 2005}

\section{Contents}

Editor's Note

\section{EsSAYS}

The Public Good and the Problem of Pluralism in Lincoln Steffens's

Civic Imagination

James J. Connolly

Antiquity Bound: The Loeb Classical Library as Middlebrow Culture in the Early Twentieth Century

Kevin B. Sheets

Performing 'Jiggs': Irish Caricature and Comedic Ambivalence toward Assimilation and the American Dream in George McManus's Bringing Up Fatber

Kerry Soper

\section{BOOK REVIEWS}

Desperately Seeking the Progressives

Maureen A. Flanagan

The Catholic Church and New England City Politics

Deirdre M. Moloney

A Presidential Election: Historical Analogies, 1876

Murney Gerlach

[On the back cover: Frame from Bringing Up Father, November 18, 1923.

(C) Reprinted with special permission of King Features Syndicate.] 
The Journal of the Gilded Age and Progressive Era is a peer-reviewed journal published quarterly by the Society for Historians of the Gilded Age and Progressive Era (SHGAPE), with assistance from the Rutherford B. $\overrightarrow{\mathrm{w}}$ Hayes Presidential Center, Illinois State University, and the College of William and Mary. It publishesoo original scholarly essays covering the period 1865 through the 1920 s and reviews scholarly books on that time period.

Subscription rates are $\$ 40$ for individuals, $\$ 80$ for institutions, $\$ 15$ for graduate students with proof of $\frac{}{\mathrm{C}}$ enrollment, $\$ 50$ for joint membership (one Journal subscription and two memberships to the Society). $\frac{\bar{v}}{\bar{v}}$ There is an additional charge of $\$ 5$ for subscriptions from outside of the United States, including Canada and Mexico. For subscriptions or single issues please contact Suzanne Darr, Executive Assistant, Rutherford B. Hayes Presidential Center, Spiegel Grove, Fremont, OH 43420, or <sdarr@rbhayes.org > Subscriptions includes SHGAPE membership, which also brings a semi-annual Newsletter and notices of SHGAPE sessions at annual conferences of the American Historical Association and the Organization of $\frac{3}{0}$ American Historians.

Manuscripts should be sent in triplicate to the editor, Alan Lessoff, Department of History, Illinois State University, Normal, IL 61790-4420. Before submitting any manuscript, please consult the website $<$ www.jgape.org > for details on correct format and citation style. Information may also be obtained at the email address<ahlesso@ilstu.edu>.

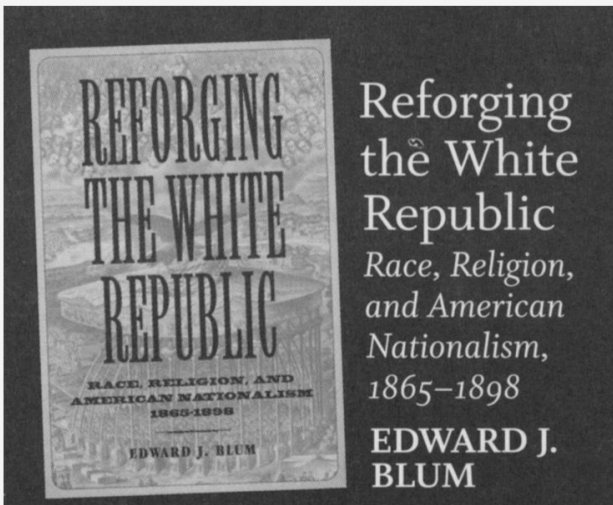

"Explores the ways that evangelical Protestantism in the North forged a new sense of American nationalism that privileged white Americans at the expense of African Americans who remained segregated and politically disenfranchised. A first-rate intellectual and cultural history."-Harry S. Stout, coeditor, Religion and the American Civil War

Conflicting Worlds: New Dimensions of the American Civil War

T. Michael Parrish, Editor

Illustrated, $\$ 54.95$

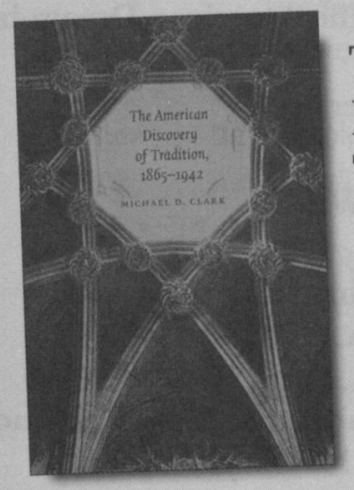

The American Discovery of Tradition, $1865-1942$ MICHAEL D. CLARK Challenging reigning assumptions, Clark maintains that in the period between the Civil War and World War II Americans became more conscious of tradition as a social force, viewed it more positively, and used it more eclectically and selectively for personal and social enrichment.

"Poses a provocative challenge to familiar assumptions about American faith in progress."-T. J. Jackson Lears, author of No Place of Grace

$\$ 44.95$

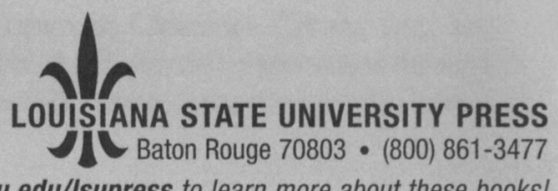

Visit www.Isu.edu/lsupress to learn more about these books! 